Fidei: Jurnal Teologi Sistematika dan Praktika, Vol. 4, No. 1, Juni 2021

Fidei: Jurnal Teologi Sistematika dan Praktika

Terakreditasi No: 85/M/KPT/2020 (Sinta 4)

e-ISSN: 2621.8135

http://www.stt-tawangmangu.ac.id/e-journal/index.php/fidei

Vol. 4 No.1 (Juni 2021) hlm: 24-43

p-ISSN: $2621-8151$

DOI: https://doi.org/10.34081/fidei.v4i1.178

\title{
Peran Dosen Mengatasi Permasalahan Pembelajaran Online Pada Masa Pandemi Covid-19
}

\author{
Jakson Sespa Toisuta ${ }^{1)^{*}}$ \\ $\left.{ }^{1}\right)$ Sekolah Tinggi Teologi Blessing Indonesia Makassar, Indonesia \\ *) Email: jakson.toisuta28@gmail.com
}

Diterima: 01 Okt. 2020

Direvisi: 12 Apr. 2021

Disetujui: 19 Mei 2021

\begin{abstract}
Abstrak
Seluruh dunia tergoncang akibat munculnya pandemi Covid-19. Tidak terkecuali dunia pendidikan. Sekolah dan kampus akhirnya ditutup dan diharuskan belajar dari rumah secara online sebagai salah satu cara memutus rantai penyebaran Covid-19. Tujuan dari penelitian ini adalah untuk mengetahui peran dosen dalam mengatasi permasalahan pembelajaran jarak jauh secara online terhadap mahasiswa di Sekolah Tinggi Teologi Blessing Indonesia Makassar pada masa pandemi Covid-19. Metode penelitian, deskriptif kualitatif. Data diperoleh dengan wawancara, observasi dan analisis dokumentasi. Responden sebanyak 8 orang dosen, data wawancara di transkrip secara verbatim kemudian dianalisa dan disimpulkan. Hasil penelitian didapatkan tiga tema, yaitu: Pertama; ditetapkan platform WhatsApp Grup sebagai media utama yang digunakan dalam proses belajar online, karena dianggap lebih sederhana, efisien dan hemat biaya bagi mahasiswa yang mayoritas di daerah yang sulit terjangkau signal internet. Kedua; beberapa dosen siap membantu mahasiswa dengan menyalurkan dana dalam jumlah tertentu untuk memenuhi kebutuhan kuota internet mahasiswa, memberikan pendampingan motivasi belajar dengan terus membangun komunikasi yang bersahabat dengan mahasiswa melalui whatsapp group diluar jam perkuliahan. Ketiga; harapan dari dosen kepada mahasiswa adalah mahasiswa bisa membangun konsep belajar mandiri (Self Regulated Learning) untuk mengembangkan pengetahuan, karakter dan
\end{abstract}


kerohaniannya (aspek kognitif, afektif dan psikomotorik) sekalipun jauh dari kontrol dan pengawasan dosen secara langsung.

Kata-Kata Kunci: Peran Dosen; Permasalahan Pembelajaran Online; Pandemi Covid-19

\section{Abstract}

The whole world is shaken by the emergence of the Covid-19 pandemic. The world of education is no exception. Schools and campuses were eventually closed and required to study from home online as a way to break the chain of spreading Covid-19. This study aims to determine the rule of the lecturers in solving problems of online distance learning for students at the Blessing Indonesian College of Theology in Makassar during the Covid-19 pandemic. Research method, qualitative descriptive. Data obtained by interview, documentation analysis and observation. The respondents were 8 lecturers, all of interview data to transcribed in verbatim then analyzed and made a conclusion. The results obtained three themes, namely: First; WhatsApp Group platform was established as the main media used in the online learning process, because it is considered simpler, more efficient and cost-effective for students, the majority of whom are in areas where internet signal is difficult to reach. Second; Several lecturers are ready to help students by channeling a certain amount of funds to sufficient for students' internet quota needs, providing learning motivation assistance by continuing to build friendly communication with students through WhatsApp groups outside of class hours. Third; The hope of the lecturers to students is that students can build the concept of selfregulated learning to develop their knowledge, character and spirituality (cognitive, affective and psychomotor aspects) even though they are far from direct control and supervision of the lecturer.

Keywords: Covid-19 pandemic; Lecturer Role; Online Learning Problems.

\section{Pendahuluan}

Dunia tidak sama lagi ketika digoncangkan dengan munculnya Pandemi virus corona (Coronavirus Disease 2019) atau biasa disebut Covid-19 semenjak pertama kali muncul pada sekitar pertengahan Desember 2019 di Wuhan, salah satu kota di Provinsi Hubei China. Menurut World Health Organization (WHO), Covid-19 merupakan penyakit menular yang dapat menimbulkan resiko mematikan yang cepat dan tinggi yang disebabkan oleh Coronavirus jenis baru 
yang dapat menular melalui droplet atau percikan air dari hidung atau mulut dari lndividu yang terjangkit Covid-19 saat orang tersebut batuk atau bersin. ${ }^{1}$

Pemerintah akhirnya mengambil langkah kebijakan dan mengeluarkan peraturan untuk membatasi pergerakan sosial masyarakat sebagai upaya untuk mencegah dan memutus siklus penyebaran Covid-19, yang disebut dengan PSBB atau Pembatasan Sosial Berskala Besar. Dengan diterapkannya PSBB, hal itupun berdampak kepada dunia pendidikan secara nasional, yang akhirnya membuat lembaga Kementrian Pendidikan di Indonesia harus mengeluarkan peraturan untuk tidak melaksanakan proses belajar mengajar di sekolah secara tatap muka, dan digantikan dengan kegiatan belajar secara daring atau online dari rumah yang dikenal dengan istilah e-learning atau belajar sistem online yang terkoneksi dalam jaringan internet. ${ }^{2}$ Kebijakan tersebut berdasarkan keppres No. 11 Tahun 2020, mengenai Penetapan Kebijakan Kedaruratan terhadap Kesehatan Masyarakat terkait pandemi Covid-19; Surat edaran dari Mendikbud No. 46962/MPK.A/HK/2020, tentang penetapan Pembelajaran yang dilaksanakan secara daring serta bekerja dilakukan dari rumah saja, dalam rangka untuk mencegah Penyebaran Covid-19 pada Perguruan Tinggi, serta Surat Edaran dari Mendikbud No. 4 Tahun 2020, tentang tata pelaksanaan Kebijakan Pendidikan dalam masa darurat penyebaran virus Corona. ${ }^{3}$

Dari penerapan kebijakan pembelajaran jarak jauh secara online, muncullah beberapa persoalan atau permasalahan yang terjadi, seperti terjadinya kesenjangan sumber daya dan terbatasnya sarana penunjang belajar secara online. Hal ini disebabkan karena tidak semua peserta didik mempunyai fasilitas belajar yang memadai atau mendukung seperti gadget, koneksi internet, atau bahkan minimnya aliran listrik, apalagi bagi mereka yang tinggal di daerah terluar, terdepan, dan terpencil (daerah 3T). ${ }^{4}$ Berdasarkan fakta tersebut, dosen sebagai ujung tombak dalam proses kegiatan pembelajaran di perguruan tinggi harus dapat mengaplikasikan perannya secara maksimal untuk mengatasi persoalan yang muncul pada kegiatan belajar mengajar secara online. Dalam

${ }^{1}$ Bayu Setiaji and Pri Ariadi Cahya Dinata, "Analisis Kesiapan Mahasiswa Jurusan Pendidikan Fisika Menggunakan E-Learning Dalam Situasi Pandemi Covid-19," Jurnal Inovasi Pendidikan IPA 6, no. 1 (2020): 59-70.

${ }^{2}$ Matdio Siahaan, "Dampak Pandemi Covid-19 Terhadap Dunia Pendidikan," Jurnal Kajian Ilmiah 1, no. 1 (2020): 73-80.

${ }^{3}$ Muktiono Waspodo, "Pembelajaran Daring Di Masa Pandemi Covid -19 Komang," COVID-19: Perspektif Pendidikan, no. October (2020): 11.

${ }^{4}$ Humaira Aliya, "Ketahui Dampak Corona Bagi Dunia Pendidikan Indonesia Dan Mancanegara," Glints.Com, 2020. 
pembelajaran secara online dosen juga dituntut mampu membangun komunikasi dua arah, sehingga proses pembelajaran online berjalan dengan baik. ${ }^{5}$ Jika ditinjau dari sisi pembinaan akademik dan mahasiswa, dosen mempunyai peran yang sangat strategis di perguruan tinggi. Dosen harus bisa menjadi agen perubahan (agent of change) bagi perilaku mahasiswa. Dosen berada pada garis terdepan dalam menentukan kualitas pelayanan pendidikan "front line provider and determine the quality of service delivery system, ". 6

Berbagai media dapat digunakan untuk mendukung pelaksanaan pembelajaran secara online. Aplikasi-aplikasi yang dapat digunakan dalam kelas virtual diantaranya seperti layanan Schoology, Googlemeet, Edmodo dan Google Classroom, dapat juga menggunakan aplikasi WhatsApp. Kegiatan belajar online bahkan dapat dilakukan melalui media sosial seperti Facebook dan Instagram. ${ }^{7}$ Namun dari kesemuanya itu, muncul tantangan lain yang harus dihadapi selain ketersediaan layanan internet, yakni kendala ketersediaan biaya. Mahasiswa menyatakan bahwa untuk mengikuti pembelajaran jarak jauh secara online, mereka harus mengeluarkan biaya lebih untuk membeli kuota data internet berkisar antara Rp.80.000 hingga Rp.200.000 per minggu jika dalam pembelajaran online menggunakan aplikasi video conference.

Sebagaimana diketahui bahwa sebagian mahasiswa Sekolah Tinggi Teologi Blessing Indonesia Makassar adalah mahasiswa yang berasal dari daerah 3T dan kurang mampu secara ekonomi, ketika harus menghadapi proses pembelajaran secara online, menjadi sebuah hal yang sulit bagi mereka karena keterbatasan biaya untuk membeli kuota internet, fasilitas gadget juga kurang mendukung, dan tempat tinggal di daerah yang sulit mendapatkan akses jaringan internet. Dari observasi lapangan, ditemukan bahwa ada beberapa mahasiswa yang terkadang harus naik ke tempat tinggi seperti gunung demi untuk mendapatkan signal dan koneksi jaringan internet agar bisa mengikuti kelas belajar secara online.

Berdasarkan permasalahan tersebut di atas, penulis ingin meniliti bagaimana peran dosen di Sekolah Tinggi Teologi Blessing Indonesia Makassar dalam mengatasi persoalan-persoalan yang terjadi dalam proses pelaksanaan belajar mengajar secara online/pembelajaran jarak jauh terhadap mahasiswa,

${ }^{5}$ Sister Buulolo et al., "Pembelajaran Daring: Tantangan Pembentukan Karakter Dan Spiritual Peserta Didik," Peada: Jurnal Pendidikan Kristen 1, no. 2 (2020): 129-143.

${ }^{6}$ Bambang Sumardjoko, "Faktor-Faktor Determinan Peran Dosen Dalam Penjaminan Mutu Perguruan Tinggi," Jurnal Cakrawala Pendidikan 3, no. 3 (2010): 294-310.

7 Firman and Sari Rahayu, "Pembelajaran Online Di Tengah Pandemi Covid-19," Indonesian Journal of Educational Science (IJES) 2, no. 2 (2020): 81-89. 
supaya proses perkuliahan atau proses pembelajaran tetap bisa berjalan sebagaimana mestinya, guna tercapainya tujuan proses belajar mengajar yang diharapkan.

\section{Metode Penelitian}

Penelitian ini adalah penelitian lapangan (field research) dengan pendekatan deskriptif kualitatif, yang merupakan metode untuk meneliti status sekelompok manusia, suatu objek dengan tujuan membuat deskriptif, gambaran atau lukisan secara sistematis, faktual dan akurat mengenai fakta-fakta atau fenomena yang diselidiki. ${ }^{8}$ Penelitian ini dilakukan di Sekolah Tinggi Teologi Blessing Indonesia Makassar menggunakan metode kualitatif dan pendekatan penelitiannya menggunakan metode studi kasus deskriptif yang digunakan untuk mendapatkan informasi mengenai bagaimana peran dosen untuk mengatasi permasalahan yang terjadi pada proses pembelajaran jarak jauh secara online/daring. ${ }^{9}$ Metode pengumpulan data primer dengan wawancara bebas terpimpin, sedangkan data sekunder didapatkan dari melakukan observasi di lapangan, serta melakukan kajian dan perbandingan dari penelitian-penelitian sebelumnya yang diperoleh dari artikel jurnal yang dipublikasikan, maupun buku-buku yang berhubungan dengan penelitian. Sampel atau responden ditetapkan dengan menggunakan metode purposive sampling. ${ }^{10}$ Tidak ada batasan jumlah tertentu dalam penentuan responden untuk membuat sampel purposive, asalkan informasi yang diinginkan telah dapat diperoleh dan dihasilkan. ${ }^{11}$ Data wawancara dan observasi yang diperoleh kemudian dideskripsikan menjadi data verbatim, selanjutnya dibahas untuk mendapatkan hasil dan kesimpulan penelitian.

${ }^{8}$ Purnama Sari and Devi Yanuarti Eka, "Peran Dosen Dalam Memanfaatkan Media Sosial Sebagai Sarana Literasi Pembelajaran Mahasiswa," JOEAI (Journal of Education and Instruction) 2, no. 2 (2019).

${ }^{9}$ Agus Purwanto et al., "Studi Eksploratif Dampak Pandemi COVID-19 Terhadap Proses Pembelajaran Online Di Sekolah Dasar," EduPsyCouns: Journal of Education, Psychology and Counseling 2, no. 1 (2020): 1-12.

${ }^{10}$ Anwar Hidayat, "Penjelasan Teknik Purposive Sampling Lengkap Detail," Metodologi Penelitian, 2017.

${ }^{11}$ Risa Rosalia and A. Jauhar Fuad, "Peran Dosen Dalam Meminimalisasi Perilaku Plagiasi Mahasiswa," Indonesian Journal of Islamic Education Studies (IJIES) 2, no. 1 (2019): 61-77. 


\section{Pembahasan dan Hasil}

Bukti sederhana dari implementasi manusia sebagai ciptaan Tuhan yang mulia adalah mau belajar. Dalam proses kegiatan belajar berarti peserta didik akan menerima materi ajar, dan peserta didik mampu mengungkapkannya kembali apa yang dipelajarinya dalam bentuk tanggapan dan perilaku. ${ }^{12}$ Berbagai faktor dapat mempengaruhi keberlangsungan proses belajar mengajar. Baik itu faktor yang datang dari dalam diri subjek belajar, dari luar diri subjek belajar, maupun dari metode belajar yang akan digunakan dalam proses pembelajaran. Jadi keberhasilan suatu proses belajar dan pembelajaran tidak terlepas dari faktor-faktor yang mempengaruhinya. ${ }^{13}$

Salah satu bentuk perkembangan dan kemajuan teknologi informasi saat ini yang dapat dimanfaatkan sebagai media dalam kegiatan pembelajaran adalah menggunakan e-learning. ${ }^{14}$ Dalam pengertian sederhana, pembelajaran online atau yang dikenal dengan istilah e-learning dapat diartikan sebagai suatu aktifitas pembelajaran atau interaksi belajar-mengajar yang berlangsung dengan menggunakan jaringan internet, dimana antara pengajar dan peserta ajar saling terkoneksi dalam jaringan internet. ${ }^{15}$ Konsep belajar mengajar secara online yang kemudian lebih dikenal dengan istilah e-learning, model interaksinya berbeda dengan pembelajaran konvensional (conventional learning). Pada model conventional learning (c-learning), dosen dan mahasiswa bertemu muka secara langsung dalam satu ruangan kelas. Berbeda dengan e-learning, keduanya tidak perlu bertemu atau bertatap muka langsung dalam sebuah ruangan kelas, dan bisa melaksanakan proses pembelajaran secara online melalui koneksi internet. Hal ini karena didukung dengan kecanggihan teknologi informasi yang memfasilitasi pembelajaran secara online walaupun terpisah ruang, jarak dan waktu. ${ }^{16}$

Pada sebuah penelitian menunjukkan bahwa e-learning cukup efektif bagi mahasiswa tanpa memperhatikan latar belakang mahasiswa. E-learning dapat dikatakan sebagai suatu langkah terobosan baru bagi masa depan dunia

${ }^{12}$ Hendro Hariyanto Siburian and Arif Wicaksono, "Makna Belajar Dalam Perjanjian Lama Dan Implementasinya Bagi PAK Masa Kini," FIDEI: Jurnal Teologi Sistematika dan Praktika 2, no. 2 (2019).

${ }^{13}$ Ibid.

${ }^{14}$ Cecilia Engko and Paul Usmany, "Dampak Pandemi Covid-19 Terhadap Proses Pembelajaran Online," Jurnal Akuntansi 6, no. 1 (2020): 23-38.

${ }^{15}$ Tri Adi Prasetya and Chrisna Tri Harjanto, "Pengaruh Mutu Pembelajaran Online Dan Tingkat Kepuasan Mahasiswa Terhadap Hasil Belajar Saat Pandemi Covid19," Jurnal Pendidikan Teknologi dan Kejuruan 17, no. 2 (2020): 188-197.

${ }^{16}$ Ibid. 
pendidikan karena cara belajarnya interaktif, menarik, menghibur dan akan segera menggantikan buku-buku kertas kedalam bentuk aplikasi gadget atau tablet layar sentuh. ${ }^{17}$

Menurut Moore, Dickson-Deane \& Galyen dalam tulisan Firman, menyatakan bahwa pembelajaran online merupakan sebuah sistem pembelajaran yang menggunakan jaringan internet dengan aksesibilitas, konektivitas, fleksibilitas, dan kemampuan untuk memunculkan berbagai jenis interaksi pembelajaran. ${ }^{18}$ Zhang et.al, dalam penelitiannya menunjukkan bahwa dengan penggunaan internet dan teknologi multimedia akan mampu menguraikan sebuah metode yang baru dalam penyampaian pengetahuan dan dapat menjadi alternatif dari pembelajaran yang dilaksanakan pada umumnya dalam kelas tatap muka secara tradisional. ${ }^{19}$

Haugey \& Anderson, dalam buku Networked Learning: The Pedagogy of The Internet menjelaskan bahwa terdapat tiga model e-learning, yakni Pertama; Web Course, yaitu perkuliahan yang dilakukan melalui web adalah sebuah metode belajar online secara utuh. Artinya bahwa dalam berlangsungya proses pembelajaran online, pola komunikasi antara mahasiswa dan dosen tidak terjadi pertemuan tatap muka secara langsung dalam ruangan kelas, tetapi didominasi sistem jarak jauh melalui internet/web. Seluruh kegiatan belajar mengajar seperti konsultasi, ujian, penugasan, pemberian bahan ajar dan kegiatan pembelajaran lainnya disampaikan melalui internet. Kedua; Web Centric Course, yaitu penggabungan metode pembelajaran tatap muka secara langsung dan metode belajar jarak jauh. Dalam pemberian materi pada perkuliahan model ini, sebagian materi diberikan melalui tatap muka secara langsung, sebagiannya lagi diberikan melalui web atau internet, dan kedua metode ini saling melengkapi. Ketiga; Web Enhanced Course yaitu metode perkuliahan yang lebih ditingkatkan lagi dengan pemanfaatan web/internet, yakni pembelajaran tersebut terjadi timbal balik antara dosen dan mahasiswa serta pembelajaran berpusat pada web/internet". ${ }^{20}$

Dalam pelaksanaan pembelajaran secara online (e-learning), dosen sebagai pengajar dan mahasiswa sebagai peserta didik memiliki perannya masing-masing. Dosen memiliki peran sebagai yang memfasilitasi dan

${ }^{17}$ Ibid.

${ }^{18}$ Firman and Rahayu, "Pembelajaran Online Di Tengah Pandemi Covid-19."

${ }^{19}$ Ibid. Online."

${ }^{20}$ Engko and Usmany, "Dampak Pandemi Covid-19 Terhadap Proses Pembelajaran 
membimbing dalam kegiatan belajar mengajar, sedangkan mahasiswa mempunyai peran sebagai yang mengembangkan pengetahuan, pembelajar mandiri (independent learners), dan sebagai aktor intelektual dalam pemecah masalah (problem solvers). ${ }^{21}$ Dalam proses belajar mengajar secara online, mahasiswa dituntut untuk berperan aktif. Sebab dengan keaktifan mahasiswa, akan meningkatkan hasil belajar mahasiswa tersebut dan dapat mengatasi kejenuhan dalam proses pembelajaran secara online. Selain daripada itu, dosen sebagai aktor utama untuk mencapai keberhasilan proses pembelajaran secara online, harus bisa memiliki ketepatan dalam pemilihan media pembelajaran sehingga proses e-learning ini dapat berjalan dengan maksimal dan efektif. ${ }^{22}$ Dosen perlu mengembangkan media belajar dalam proses belajar online, sebab itu dosen harus memiliki atau menggunakan bahan pengajaran yang sesuai dengan: kurikulum, karakteristik sasaran ajar yaitu mahasiswa, kemudian media yang akan digunakan, serta hasil yang diharapkan akan dicapai. ${ }^{23}$

Setelah melakukan observasi terhadap rencana penetapan penggunaan media platform yang akan digunakan dalam proses pembelajaran online di Sekolah Tinggi Teologi Blessing Indonesia Makassar, kemudian dilakukan wawancara kepada para responden, dan mengkaji sumber-sumber data yang lain, maka ditemukan hasil sebagai berikut:

Jumlah responden dalam penelitian ini adalah sebanyak 8 orang dosen. Diantaranya adalah 5 orang dosen dari program studi Teologi, dan 3 orang dosen dari program studi Pendidikan Agama Kristen (P.A.K). Demi menjaga kerahasiaan, maka responden diberi kode; D1, D2, D3, D4, D5, D6, D7, dan D8, sesuai yang dirincikan pada table 1 .

Tabel. 1

Data Responden

\begin{tabular}{cccccc}
\hline Kode & L/P & $\begin{array}{c}\text { Umur } \\
\text { (Thn) }\end{array}$ & Status & Pendidikan & $\begin{array}{c}\text { Program } \\
\text { studi }\end{array}$ \\
\hline D1 & Perempuan & 45 & Single & S2 & Teologi \\
D2 & Laki-laki & 48 & Menikah & S2 & Teologi \\
D3 & Perempuan & 51 & Menikah & S3 & Teologi \\
D4 & Laki-laki & 58 & Menikah & S3 & Teologi
\end{tabular}

${ }^{21}$ Ibid.

${ }^{22}$ Prasetya and Harjanto, "Pengaruh Mutu Pembelajaran Online Dan Tingkat Kepuasan Mahasiswa Terhadap Hasil Belajar Saat Pandemi Covid19."

${ }^{23}$ Emmilia Rusdiana and Arinto Nugroho, "Respon Pada Pembelajaran Daring Bagi Mahasiswa Mata Kuliah Pengantar Hukum Indonesia," Integralistik 19, no. 2 (2017): 148-152. 
32 Fidei: Jurnal Teologi Sistematika dan Praktika, Vol. 4, No. 1, Juni 2021

\begin{tabular}{cccccc} 
D5 & Laki-laki & 49 & Menikah & S3 & P.A.K \\
D6 & Laki-laki & 56 & Menikah & S3 & Teologi \\
D7 & Perempuan & 44 & Menikah & S2 & P.A.K \\
D8 & Perempuan & 63 & Menikah & S3 & P.A.K \\
\hline
\end{tabular}

Semua responden diwawancara satu persatu dan disalin dalam catatan wawancara, kemudian hasil wawancara ditranskrip secara verbatim dalam bentuk teks naratif, Untuk menggali dan mendapatkan informasi mengenai peran dosen dalam mengatasi permasalahan sistem pembelajaran jarak jauh secara online terhadap mahasiswa di Sekolah Tinggi Teologi Blessing Indonesia Makassar, dibuat pertanyaan penelitian yang diajukan kepada responden, antara lain sebagai berikut: Pertama, magaimana persiapan anda menghadapi proses belajar mengajar dengan sistem yang baru secara online? Kedua, metode apa yang akan digunakan dalam proses pembelajaran secara online? Ketiga, apa yang dilakukan untuk mendukung mahasiswa supaya bisa mengikuti proses belajar secara online? Keempat, apa harapan terhadap mahasiswa dengan adanya proses belajar jarak jauh secara online ini tanpa tatap muka secara langsung?

Jawaban yang diperoleh dari para responden adalah:

Jawaban dari Responden 1 (D1): "Sesuai kesepakatan rapat bersama dosen, bahwa pembelajaran menggunakan metode/platform WAG chat (WhatsApp Group), kemudian sesekali akan menggunakan platform zoom. Materi kuliah disusun dengan Microsoft word dan power point kemudian dibagikan kepada mahasiswa. Akan dibuka ruang diskusi melalui chat group whatsApp. Sesekali akan melakukan quiz dipertengahan kuliah sekaligus sebagai pemantau keaktifan mahasiswa, serta membuat kelompok-kelompok diskusi didalam grup whatsApp."

Jawaban Responden 2 (D2): "Menggunakan platform whatsApp group, sesekali menggunakan aplikasi zoom untuk proses pembelajaran. Akan mengscan materi ajar dan dibagikan kepada mahasiswa. Siap mendukung proses belajar mengajar dengan memberikan bantuan kuota internet kepada mahasiswa. Terus memantau keaktifan mahasiswa melalui WAG chat dan akan memberikan reward kepada mahasiswa yang patut mendapatkannya."

Jawaban Responden 3 (D3): "Sistem pembelajaran yang sama, menggunakan platform chating WhatsApp Grup (WAG), sesekali akan menggunakan aplikasi zoom, akan mendukung mahasiswa melalui institusi 
dengan memberi bantuan dana bagi pembelian kuota internet kepada setiap mahasiswa", terus memantau mahasiswa melalui interaksi chating WAG."

Jawaban Responden 4 (D4): "Akan menggunakan metode WhatsApp grup chating, membagikan power point dan akan dijelaskan kemudian. Akan aktif melakukan Interaksi dengan mahasiswa melalui WAG chat sebagai bentuk kepedulian kepada mahasiswa untuk membangun ikatan emosional sebagai pendidik dan murid, tidak hanya membangun pengetahuan secara kognitif tetapi juga membangun sisi afektif dari mahasiswa. Mengusulkan supaya ada satu rumah jemaat didaerah yang dijadikan sebagai tempat untuk dipasangkan provider internet atau pusat jaringan wifi, dan dijadikan sebagai posko atau tempat utama perkuliahan mahasiswa."

Jawaban Responden 5 (D5): "Mempersiapkan metode pengajaran dengan WhatsApp grup chating, membuat video mengajar lengkap dengan power point, kemudian dibagikan kepada mahasiswa, melakukan diskusi melalui WAG chating."

Jawaban Responden 6 (D6): “Akan menggunakan platform WhatsApp Grup (WAG) sebagai saranan belajar mengajar, tetap peduli dengan interaksi terhadap mahasiswa melalui whatsapp group chating, apalagi tanpa pemantauan secara langsung dari dosen kepada mahasiswa, yang perlu diperhatikan juga adalah membangun karakter rohaninya bukan hanya sekedar pengetahuan."

Jawaban Responden 7 (D7): "Akan menggunakan platform WAG sebagai media untuk proses belajar mengajar. Saya siap membantu rekan dosen yang lain, menyediakan alat scanner untuk memindahkan materi kuliah dari bentuk buku atau diktat ke dalam bentuk display pdf untuk dapat dibagikan kepada mahasiswa secara online."

Jawaban Responden 8 (D8): "akan menggunakan platform WhatsApp Grup, karena lebih mudah digunakan, hemat dan efisien khususnya dalam pemakaian kuota internet, dibandingkan menggunakan metode online yang lain misalnya zoom atau video confrence. Menyarankan kepada setiap dosen untuk menggunakan platform WAG saja supaya membantu mahasiswa lebih hemat dalam penggunaan kuota dan lebih menjangkau jika dibandingkan platform lain."

Sebanyak 8 responden telah memberikan pernyataan dan pendapat yang akan diuraikan dan dijelaskan sebagai berikut: 


\section{Persiapan dan Metode Pembelajaran yang digunakan}

Setelah melalui rapat dosen di Sekolah Tinggi Teologi Blessing Indonesia Makassar yang dilakukan untuk persiapan pelaksanaan pembelajaran secara online akibat dampak pandemi covid-19, maka ditetapkanlah penggunaan platform/perangkat media pembelajaran kepada mahasiswa adalah dengan menggunakan platform WhatsApp Grup (WAG) sebagai media utama, selain menggunakan plat form lain seperti zoom, google meet, google clas room, dan beberapa aplikasi video conference lainnya sebagai pilihan kedua dalam proses pembelajaran online.

Pemilihan penggunaan platform WAG sebagai media utama dalam pembelajaran online ini karena didasarkan kepada pertimbangan mengenai keadaan mahasiswa yang sebagian besar berdomisili di daerah yang tidak semua wilayah kampung dari mahasiswa tersebut mendapatkan sinyal internet. Kalaupun ada jaringan internet, sinyal yang didapat sangat lemah sehingga jika menggunakan video konfrensi seperti zoom, google meet atau video conference lainnya, akan sulit bagi mahasiswa untuk bisa mengikuti pembelajaran karena mengalami gangguan jaringan internet akibat dari keterbatasan jangkauan sinyal internet. Alasan lain pemilihan platform $W A G$ adalah karena platform ini dianggap sebagai aplikasi yang mudah digunakan, tidak memakan kuota internet yang banyak dalam penggunaannya, efisien, ekonomis, praktis, dan diharapkan dapat efektif, mengingat bahwa sebagian mahasiswa adalah anak-anak dari keluarga petani yang kurang mampu, sehingga ketika dalam proses pembelajaran online menggunakan metode chat whatsapp group tidak terlalu membutuhkan kuota internet yang banyak maka pengeluaran keuangan untuk pembelian kuota internet dapat ditekan atau lebih berhemat jika dibandingkan dalam proses belajar online harus menggunakan media video conference seperti zoom, google meet, google class room, atau aplikasi video conference lainnya.

Dari data yang ditemukan, dikutip dari CNN Indonesia (2020) konsumsi data untuk video konferensi menggunakan aplikasi Zoom dengan kualitas video 720p selama satu jam menghabiskan data sebesar 540 MB. Di beberapa situs resmi, melalui hasil survei peneliti mengenai provider seluler menunjukkan harga kuota data sebesar 1 GB berkisar antara Rp. 20.000 hingga Rp.50.000. Jika diasumsikan bahwa rata-rata mahasiswa memprogramkan 8 mata kuliah tiap semester dan masing-masing mata kuliah melaksanakan kuliah online menggunakan aplikasi konferensi video selama kurang lebih satu jam setiap minggu, maka mahasiswa harus menghabiskan dana antara Rp.80.000 hingga 
Rp.200.000 per minggu, tergantung provider seluler yang digunakan. ${ }^{24}$ Dengan melihat hal tersebut, dan memperhitungkan keefesiensi biaya bagi mahasiswa yang kurang mampu untuk memenuhi kuota internet dalam pembelajaran online, maka dipakailah platform Whatsapp Group sebagai media utama dalam proses pembelajaran.

Pembelajaran online harus dipersiapkan dengan baik agar bisa berjalan efektif, sama halnya dengan pembelajaran klasikal tatap muka. ${ }^{25}$ Tian Belawati memaparkan sepuluh contoh pengalaman baik untuk perencenaan pembelajaran secara online adalah: ${ }^{26}$ Pertama; sebaiknya mengenal karakteristik calon pembelajar yang akan mengikuti kelas belajar online. Kedua; menentukan tujuan pembelajaran yang akan dicapai oleh pembelajar, apa luaran yang ingin dicapai, bagaimana menyusun dan mengurutkan tujuan-tujuan. Ketiga; menetapkan pedagogi yang akan digunakan apakah menggunakan satu metode atau kombinasi (blanded learning). Keempat; menetapkan aktifitas pembelajaran, apakah akan menggunakan video konferensi atau hanya bersifat asinkronus, yaitu siswa melakukan pembelajaran di waktu yang berlainan dengan gurunya, misalnya siswa mendapatkan tugas untuk dikerjakan di rumah. Kelima; menetapkan platform online yang akan digunakan setelah menentukan aktifitas pedagogi yang akan digunakan. Keenam; menetapkan materi yang akan digunakan, bisa menggunakan materi yang dibuat sendiri, atau menggunakan materi yang sudah ada. Ketujuh; menetapkan bagaimana asesmen hasil belajar yang akan ditetapkan. Kedelapan; menetapkan siapa yang bertanggung jawab dalam pelaksanaan kelas online. Kesembilan; mengidentifikasi layanan belajar yang lain selain layanan belajar yang pokok. Kesepuluh; membangun sistem analisis data yang dapat merekam aktifitas dan hasil pembelajaran. ${ }^{27}$

Kuliah jarak jauh secara online merupakan proses kegiatan belajar yang memanfaatkan keunggulan komputer dan internet sebagai media perantara antara dosen sebagai pengajar dan mahasiswa yang diajar agar mudah berkomunikasi. Kuliah jarak jauh secara online dapat menjadi sebuah media yang menyediakan bahan pengajaran yang sifatnya mandiri, dimana bahan pengajaran tersebut dapat diunduh lewat akses internet oleh siapa saja dan pada waktu yang tidak dibatasi oleh ruang dan waktu. Kuliah jarak jauh secara daring

${ }^{24}$ Firman and Rahayu, "Pembelajaran Online Di Tengah Pandemi Covid-19."

25 Tian Belawati, Buku Pembelajaran Online (Universitas Terbuka Kementerian Pendidikan dan Kebudayaan Tangerang Selatan - 15437, Banten - Indonesia, 2020).

${ }^{26}$ Ibid.

${ }^{27}$ Ibid. 
dapat memberikan kesempatan kepada mahasiswa agar bisa belajar secara mandiri karena tidak dibatasi oleh waktu dan tempat belajar, sebab proses belajar daring dapat dilakukan melalui jaringan internet. ${ }^{28}$

\section{Yang dilakukan Dosen untuk mendukung mahasiswa dalam pembelajaran online}

Undang-Undang Tahun 2005 Nomor 14 yang mengatur tentang Dosen dan Guru, menjelaskan bahwa seorang dosen adalah pendidik yang profesional dan seorang ilmuwan dengan tugas utamanya adalah mentransferkan ilmu pengetahuan, mengembangkannya, dan menyebarluaskannya, baik itu bidang teknologi, juga di bidang seni yang dilaksanakan melalui lingkup pendidikan, pelaksanaan penelitian, dan melakukan pengabdian diri di lingkup masyarakat. ${ }^{29}$

Salah satu bagian yang sangat berpengaruh pada kualitas mahasiswamahasiswi yang dihasilkan sebuah perguruan tinggi adalah peran dosen dari perguruan tinggi tersebut, tentunya dengan standart dosen yang memiliki kualitas lebih dari mahasiswa. ${ }^{30}$ Dalam mengajar, dosen harus memperhatikan gaya belajar mahasiswa. Ini disebabkan karena efektifitas mengajar akan sangat bergantung pada cara atau gaya belajar mahasiswa di setiap pengajaran dosen, disamping sifat pribadi dan kemampuan intelektual dari mahasiswa itu sendiri. Kurangpahamnya dosen terhadap gaya belajar mahasiswa akan berpotensi memberikan dampak merugikan kepada mahasiswa. Salah satunya adalah dapat menyebabkan ketidakselarasnya prestasi belajar mahasiswa dengan tingkat kemampuan inteligensi mahasiswa tersebut. Sebab itu, dosen harus mengetahui dan mengenal gaya belajar setiap mahasiswa sehingga bisa mempermudah proses pembelajaran. ${ }^{31}$

Sebagai tugas dan tanggung jawab yang penting dari seorang pendidik di lingkungan kampus, dosen atau guru harus bisa membangkitkan minat belajar siswa. Dosen atau guru dituntut harus bisa menguasai semua keterampilan yang

${ }^{28}$ Selamat Riadi et al., "Persepsi Mahasiswa Prodi S1 Geografi FISIP ULM Terhadap Kuliah Online Di Masa Pandemi," Jurnal Pendidikan Sosiologi Antropologi FKIP ULM 2, no. 2 (2020): 219-227.

${ }^{29}$ Suranto Trie Hartiti Retnowati , Djemari Mardapi, Badrun Kartowagiran, "Model Evaluasi Kinerja Dosen: Pengembangan Instrumen Untuk Mengevaluasi Kinerja Dosen,” Jurnal Penelitian dan Evaluasi Pendidikan 21, no. 2 (2017): 206-214.

${ }^{30}$ Nasrun Marpaung, Masitah Handayani, and Rolly Yesputra, "Sistem Pendukung Keputusan Pemilihan Dosen Terbaik Dengan Metode Weighted Product (WP) Pada STMIK Royal," Seminar Nasional Royal 2018 9986, no. September (2018): 267-270.

31 Jeanete Ophilia Papilaya and Neleke Huliselan, "Identifikasi Gaya Belajar Mahasiswa,” Jurnal Psikologi Undip 15, no. 1 (2016): 56. 
diperlukan dalam pengajaran, antara lain menguasai materi ajar, dan memiliki sarana metode ajar yang menarik dan bervariasi. Jika dosen atau guru tidak menggunakan variasi dalam kegiatan belajar mengajar, peserta didik akan cepat bosan dan jenuh terhadap materi pelajaran. ${ }^{32}$ Suardana dalam tulisannya menyatakan bahwa pendidik yang dikatakan berhasil adalah pendidik yang mampu meningkatkan pemberdayaan anak didiknya sehingga mereka mampu belajar dengan efektif. Sebagai salah satu contoh yang dapat ditempuh adalah dengan mengembangkan kemandirian belajar anak didik dalam pembelajaran. ${ }^{33}$

Seorang dosen harus bisa menggunakan fasilitas teknologi informatika yang ada untuk mendukung pelaksanaan belajar secara online, guna mencukupi kebutuhan belajar mahasiswa. Agar pembelajaran online dapat berhasil dengan baik, terdapat hal yang penting untuk dipenuhi yaitu perlu adanya tutorial. Dengan adanya tutorial yang dipersiapkan dengan baik oleh dosen maka akan memudahkan mahasiswa untuk memahami pembelajaran tersebut. Dengan demikian diharapkan kebingungan mahasiswa pada pembelajaran online dapat dihilangkan. Pengembangan tutorial menjadi penting di sini, sebab itu tutorial harus dikembangkan secara sistematis dan teruji. ${ }^{34}$

Berdasarkan permasalahan-permasalahan yang ditemukan dalam kegiatan belajar secara daring ini, maka yang harus dilakukan oleh seorang dosen adalah: dosen harus bisa mempersiapkan diri dan segala sesuatunya untuk mendukung pembelajaran online, seperti harus lebih bisa menguasai media internet, dosen harus lebih bisa kreatif dalam mempersiapkan dan menyusun metode belajar mengajar sehingga dapat diterima dan dipelajari oleh mahasiswa secara baik dan efektif, seperti jawaban dari beberapa responden mengatakan bahwa akan menyiapkan video penuntun pembelajaran yang direkam sebelumnya dan dibagikan kepada mahasiswa, serta membagikan materi belajar dalam bentuk power point. Seorang responden bahkan bersedia menyiapkan alat scanner demi membantu dosen yang lain untuk memindahkan materi ajar dari bentuk buku atau diktat manual kedalam bentuk digital display $p d f$ dan dibagikan kepada mahasiswa.

\footnotetext{
32 Talizaro Tafonao, "Peranan Media Pembelajaran Dalam Meningkatkan Minat Belajar Mahasiswa," Jurnal Komunikasi Pendidikan 2, no. 2 (2018): 103.

33 I Kade Suardana, "Implementasi Model Belajar Mandiri Untuk Meningkatkan Aktivitas, Hasil, Dan Kemandirian Belajar Mahasiswa," Jurnal Pendidikan dan Pengajaran 45, no. 1 (2012): 56-65.

${ }^{34}$ Sukardi Sukardi and Muhammad Hudan Rahmat, "Pencapaian Hasil Belajar Teori Kejuruan Ditinjau Dari Persepsi Mahasiswa Pada Pembelajaran Online," Jurnal Dinamika Vokasional Teknik Mesin 4, no. 2 (2019): 111-116.
} 
Salah seorang responden bahkan mengusulkan kalau boleh di salah satu daerah tertentu dipilih dan ditetapkan sebuah rumah anggota jemaat gereja yang kemudian dipasangkan pusat jaringan internet (wifi) untuk dijadikan posko kuliah online, sehingga pada saat akan dilaksanakannya jam perkuliahan, mahasiswa bisa datang ke posko tersebut untuk menggunakan jaringan wifi yang sudah disediakan guna mengikuti kuliah secara online.

Untuk mengontrol keaktifan mahasiswa dalam pembelajaran daring ini, beberapa responden akan mengadakan absensi kembali kepada mahasiswa di tengah-tengah perkuliahan, mengadakan diskusi melalui whatsapp group chating, atapun mengadakan ujian singkat/quiz, yang dijawab dalam bentuk rekaman suara (voice note), ataupun akan mengadakan video konfrensi melalui whatsapp group atau zoom, hanya dalam beberapa menit saja supaya tidak banyak membutuhkan kuota internet sebagai salah satu cara untuk mengontrol keaktifan mahasiswa mengikuti kuliah online. Responden yang lain akan mengadakan interaksi dengan mahasiswa melalui whatsapp group chating diluar jam perkuliahan, sebagai sarana untuk menjalin ikatan interaksi antara dosen dan mahasiswa, sehingga diharapkan dapat membangun sisi belajar afektif dari mahasiswa tidak hanya dari segi kognitif saja.

Responden yang lain akan memberikan 'reward' berupa bantuan dana untuk menunjang pendidikan, kepada mahasiswa yang dianggap layak mendapatkannya sesuai dengan kriteria yang ditetapkan di dalam kelas pembelajaran dosen tersebut, bahkan seorang responden lain siap mendukung program belajar online terhadap mahasiswa dengan memberikan bantuan dana dalam jumlah tertentu melalui bagian akademik yang diperuntukan kepada mahasiswa, untuk memenuhi kebutuhan kuota internet mahasiswa dalam mengikuti kuliah online selama beberapa waktu kedepan.

\section{Harapan terhadap mahasiswa selama pembelajaran jarak jauh}

Proses kegiatan belajar melalui daring seperti ini menuntut mahasiswa untuk memiliki prinsip dan semangat mandiri belajar yang penuh yang dibangun pada masing-masing pribadi mahasiswa itu sendiri. Kemandirian dalam belajar atau Self Regulated Learning adalah merupakan suatu sikap sadar secara mandiri untuk belajar dan tidak bergantung kepada orang lain, harus membangun rasa bertanggung jawab untuk mencapai tujuan yang diinginkannya. Kemandirian dalam belajar adalah merupakan salah satu hal 
penting dalam suatu pembelajaran menurut Ranti, M.G. ${ }^{35}$ Sebab, jika mahasiswa tidak mampu mengembangkan dan mengatur pola kamandirian belajar maka akan memicu munculnya stress pada mahasiswa itu sendiri karena banyaknya tuntutan-tuntutan lain dari luar yang dapat membebani mahasiswa dalam melangsungkan proses pembelajaran secara online, seperti misalnya tidak adanya jaringan internet, kehabisan kuota internet saat akan kuliah online, pekerjaan rumah yang harus diselesaikan, tuntutan akademik yang lain seperti harus menyelesaikan dan mengumpulkan tugas kuliah, dan lain sebagainya. Hal inilah yang dapat memicu munculnya stress pada mahasiswa tersebut, yang menurut Ade Chita Putri Harahap dalam tulisannya disebut dengan stress akademik. Stress akademik diartikan sebagai keadaan dimana seseorang tidak dapat menghadapi tuntutan akademik dan mempersepsi tuntutan akademik yang diterima sebagai gangguan. ${ }^{36}$ Oleh sebeb itu, dalam hal ini dosen bukan hanya hadir dan berperan sebagai pengajar saja tetapi harus hadir juga sebagai motivator dan pembimbing bagi mahasiswa, guna memberikan kontrol dan pengawasan kepada mahasiswa dalam menumbuhkembangkan kemandirian belajarnya.

Karena dosen tidak bisa memantau secara langsung aktifitas mahasiswa saat kuliah online, oleh sebab itu diharapkan semua mahasiswa dapat aktif mandiri dalam mengikuti pembelajaran, maupun diluar jam pembelajaran untuk dapat mandiri mencari tambahan informasi materi kuliah dan tugas-tugas yang diberikan. Mahasiswa diharapkan lebih giat lagi dan aktif membaca buku referensi, artikel online, jurnal-jurnal ilmiah, atau berdiskusi dengan rekan sesama mahasiswa maupun dengan dosen secara online melalui media aplikasi pesan singkat yang ada, ataupun melalui media yang lain yang dapat mendukung terlaksanannya proses pembelajaran dari mahasiswa tersebut. Pembelajaran secara online lebih bersifat student centered sehingga mampu memunculkan tanggung jawab dan otonomi mahasiswa dalam belajar. Belajar online menuntut mahasiswa untuk mempersiapkan sendiri pembelajarannya, mengatur dan mengevaluasi serta secara simultan mempertahankan motivasi

${ }^{35}$ Y Yuliati and D S Saputra, "Membangun Kemandirian Belajar Mahasiswa Melalui Blended Learning Di Masa Pandemi Covid-19," Jurnal Elementaria Edukasia 3, no. 1 (2020): 142-149.

${ }^{36}$ Ade Chita Putri Harahap, Dinda Permatasari Harahap, and Samsul Rivai Harahap, "Analisis Tingkat Stres Akademik Pada Mahasiswa Selama Pembelajaran Jarak Jauh Dimasa Covid-19," Biblio Couns : Jurnal Kajian Konseling dan Pendidikan 3, no. 1 (2020): 10-14. 
belajarnya. ${ }^{37}$ Selain mahasiswa diharapkan bisa belajar mandiri (Self Regulated Learning) untuk mengembangkan pembelajaran dari aspek kognitifnya, mahasiswa juga diharapkan dapat bertumbuh mandiri dari aspek afektif dalam menumbuhkan iman dan karakter kerohaniannya, serta aspek psikomotorik untuk mengembangkan ketrampilan dan kreatifitasnya, meskipun tanpa pemantauan dan bimbingan secara langsung dari dosen kepada mahasiswa seperti ketika mahasiswa berada dalam lingkungan perkuliahan di lingkungan kampus.

\section{Simpulan}

Berdasarkan hasil penelitian diatas dapat penulis simpulkan bahwa peran dosen dalam mengatasi permasalahan sistem pembelajaran jarak jauh secara online terhadap mahasiswa di Sekolah Tinggi Teologi Blessing Indonesia Makassar pada masa pandemi covid-19 adalah: Pertama; Ditetapkan penggunaan platform WhatsApp Grup (WAG chating, dan voice note) sebagai media utama yang akan digunakan dalam proses pembelajaran online,karena dengan mempertimbangkan aspek-aspek efisiensi dan ekonomis namun diharapkan efektif. Dosen harus bisa lebih kreatif lagi dalam mempersiapkan dan menyusun bahan mengajar supaya ketika dalam proses pembelajaran tidak menyebabkan timbulnya kejenuhan belajar dari mahasiswa. Kedua; dosen siap mendukung dan membantu mahasiswa agar terlaksananya proses belajar secara online dengan cara menyediakan alat scanner untuk memindahkan materi ajar dari buku atau diktat yang manual ke dalam bentuk digital $p d f$ untuk dibagikan kepada mahasiswa. Diusulkan supaya dibangun posko kuliah di daerah dengan menjadikan sebuah rumah jemaat yang dipasangkan provider internet (pusat jaringan wifi) sebagai sarana tempat perkuliahan online. Dosen yang lain siap memberikan reward dalam bentuk pendanaan kepada mahasiswa yang layak menerimanya sesuai kriteria yang ditetapkan dosen tersebut. Bahkan seorang dosen yang lain bersedia menyumbangkan sejumlah dana dalam jumlah tertentu untuk memenuhi kebutuhan kuota internet bagi mahasiswa selama beberapa bulan kedepan. Ketiga; besar harapan dari dosen terhadap mahasiswa adalah sekalipun proses pembelajaran secara online dan sulitnya pengawasan serta kontrol terhadap keaktifan mahasiswa, mahasiswa diharpakan dapat belajar mandiri (Self Regulated Learning) untuk mengembangkan semangat belajar

${ }^{37}$ Firman and Rahayu, "Pembelajaran Online Di Tengah Pandemi Covid-19." Indonesian Journal of Educational Science (IJES) 2, no. 2 (2020): 81-89. 
secara mandiri dalam aspek kognitif, juga mandiri dalam bertumbuh secara karakter dan kerohaniannya (aspek afektif), dan mengembangkan kreatifitas dan ketrampilannya (aspek psikomotorik).

\section{Daftar Pustaka}

Aliya, Humaira. "Ketahui Dampak Corona Bagi Dunia Pendidikan Indonesia dan Mancanegara." Glints.Com, 2020.

Belawati, Tian. Buku Pembelajaran Online. Universitas Terbuka Kementerian Pendidikan dan Kebudayaan Tangerang Selatan - 15437, Banten Indonesia, 2020.

Buulolo, Sister, Nelci Kual, Rolan Marthin Sina, and Hendro Hariyanto Siburian. "Pembelajaran Daring: Tantangan Pembentukan Karakter Dan Spiritual Peserta Didik." Peada': Jurnal Pendidikan Kristen 1, no. 2 (2020): 129-143.

Engko, Cecilia, and Paul Usmany. "Dampak Pandemi Covid-19 Terhadap Proses Pembelajaran Online." Jurnal Akuntansi 6, no. 1 (2020): 23-38.

Firman, Firman, and Sari Rahayu. "Pembelajaran Online Di Tengah Pandemi Covid-19.” Indonesian Journal of Educational Science (IJES) 2, no. 2 (2020): 81-89.

Harahap, Ade Chita Putri, Dinda Permatasari Harahap, and Samsul Rivai Harahap. "Analisis Tingkat Stres Akademik Pada Mahasiswa Selama Pembelajaran Jarak Jauh Dimasa Covid-19.” Biblio Couns : Jurnal Kajian Konseling dan Pendidikan 3, no. 1 (2020): 10-14.

Hidayat, Anwar. "Penjelasan Teknik Purposive Sampling Lengkap Detail." Metodologi Penelitian, 2017.

Marpaung, Nasrun, Masitah Handayani, and Rolly Yesputra. "Sistem Pendukung Keputusan Pemilihan Dosen Terbaik Dengan Metode Weighted Product (WP) Pada STMIK Royal.” Seminar Nasional Royal 2018 9986, no. September (2018): 267-270.

Papilaya, Jeanete Ophilia, and Neleke Huliselan. "Identifikasi Gaya Belajar Mahasiswa." Jurnal Psikologi Undip 15, no. 1 (2016): 56.

Prasetya, Tri Adi, and Chrisna Tri Harjanto. "Pengaruh Mutu Pembelajaran

Online Dan Tingkat Kepuasan Mahasiswa Terhadap Hasil Belajar Saat Pandemi Covid19." Jurnal Pendidikan Teknologi dan Kejuruan 17, no. 2 (2020): 188-197.

Purwanto, Agus, Rudy Pramono, Masduki Asbari, Priyono Budi Santoso, Laksmi Mayesti Wijayanti, Chi Hyun Choi, and Ratna Setyowati Putri. 
42 Fidei: Jurnal Teologi Sistematika dan Praktika, Vol. 4, No. 1, Juni 2021

"Studi Eksploratif Dampak Pandemi Covid-19 Terhadap Proses Pembelajaran Online Di Sekolah Dasar." EduPsyCouns: Journal of Education, Psychology and Counseling 2, no. 1 (2020): 1-12.

Riadi, Selamat, Ellyn Normelani, Muhammad Efendi, Irawaty Safitri, and Gusti Firza. "Persepsi Mahasiswa Prodi S1 Geografi FISIP ULM Terhadap Kuliah Online Di Masa Pandemi." Jurnal Pendidikan Sosiologi Antropologi FKIP ULM 2, no. 2 (2020): 219-227.

Rosalia, Risa, and A. Jauhar Fuad. "Peran Dosen Dalam Meminimalisasi Perilaku Plagiasi Mahasiswa." Indonesian Journal of Islamic Education Studies (IJIES) 2, no. 1 (2019): 61-77.

Rusdiana, Emmilia, and Arinto Nugroho. "Respon Pada Pembelajaran Daring Bagi Mahasiswa Mata Kuliah Pengantar Hukum Indonesia.” Integralistik 19, no. 2 (2017): 148-152.

Setiaji, Bayu, and Pri Ariadi Cahya Dinata. "Analisis Kesiapan Mahasiswa Jurusan Pendidikan Fisika Menggunakan E-Learning Dalam Situasi Pandemi Covid-19." Jurnal Inovasi Pendidikan IPA 6, no. 1 (2020): 59-70. Siahaan, Matdio. "Dampak Pandemi Covid-19 Terhadap Dunia Pendidikan." Jurnal Kajian Ilmiah 1, no. 1 (2020): 73-80.

Siburian, Hendro Hariyanto, and Arif Wicaksono. "Makna Belajar Dalam Perjanjian Lama Dan Implementasinya Bagi PAK Masa Kini." Fidei: Jurnal Teologi Sistematika dan Praktika 2, no. 2 (2019).

Suardana, I Kade. "Implementasi Model Belajar Mandiri Untuk Meningkatkan Aktivitas, Hasil, Dan Kemandirian Belajar Mahasiswa." Jurnal Pendidikan dan Pengajaran 45, no. 1 (2012): 56-65.

Sukardi, Sukardi, and Muhammad Hudan Rahmat. "Pencapaian Hasil Belajar Teori Kejuruan Ditinjau Dari Persepsi Mahasiswa Pada Pembelajaran Online." Jurnal Dinamika Vokasional Teknik Mesin 4, no. 2 (2019): 111116.

Sumardjoko, Bambang. "Faktor-Faktor Determinan Peran Dosen Dalam Penjaminan Mutu Perguruan Tinggi." Jurnal Cakrawala Pendidikan 3, no. 3 (2010): 294-310.

Tafonao, Talizaro. "Peranan Media Pembelajaran Dalam Meningkatkan Minat Belajar Mahasiswa." Jurnal Komunikasi Pendidikan 2, no. 2 (2018): 103.

Trie Hartiti Retnowati , Djemari Mardapi, Badrun Kartowagiran, Suranto. "Model Evaluasi Kinerja Dosen: Pengembangan Instrumen Untuk Mengevaluasi Kinerja Dosen." Jurnal Penelitian dan Evaluasi Pendidikan 21, no. 2 (2017): 206-214. 
Waspodo, Muktiono. "Pembelajaran Daring Di Masa Pandemi Covid -19 Komang." COVID-19: Perspektif Pendidikan, no. October (2020): 11.

Yanuarti Eka, Purnama Sari Devi. "Peran Dosen Dalam Memanfaatkan Media Sosial Sebagai Sarana Literasi Pembelajaran Mahasiswa." JOEAI (Journal of Education and Instruction) 2, no. 2 (2019).

Yuliati, Y, and D S Saputra. "Membangun Kemandirian Belajar Mahasiswa Melalui Blended Learning Di Masa Pandemi Covid-19." Jurnal Elementaria Edukasia 3, no. 1 (2020): 142-149. 